\title{
EFFECTS OF PAINT INDUSTRY EFFLUENT ON SOIL PRODUCTIVITY
}

\author{
Y. N. JOLLY, A. ISLAM AND S. B. QURAISHI \\ Chemistry Division, Atomic Energy Centre, P. O. Box 164 \\ Dhaka 1000, Bangladesh
}

AND

\author{
A. I. MUSTAFA \\ Department of Applied Chemistry and Chemical Technology \\ University of Dhaka, Bangladesh
}

\begin{abstract}
The impact of various dilutions $(2.5,5,10,25$ and 50\%) of paint industry effluent on physicochemical properties of soil and the germination, growth and dry matter productions of corn (Zea mays L.) and rice (Oryza sativa L.) have been studied. The effluent was acidic and had low BOD and COD values because of its low content of suspended solid. It contained high concentration of calcium, medium concentrations of nitrogen, sodium, potassium, sulphate, chloride and low concentrations of phosphorus, magnesium and bicarbonate. The trace element like $\mathrm{Mn}, \mathrm{Ni}, \mathrm{Cu}, \mathrm{Zn}$ and $\mathrm{Pb}$ were measured in the $\mu \mathrm{g} \mathrm{L}^{-1}$ level. On irrigation of soil with the effluent an increase in the water soluble salts, $\mathrm{pH}$, electrical conductivity, cation exchange capacity, nitrogen, phosphorus potassium, sodium, calcium, magnesium and iron contents of the soil for effluent concentrations of 2.5, 5 and $10 \%$ were observed but all these parameters were found to decrease on treatment of the soil with the effluent concentration of $25 \%$ and above. The effluent of the lower concentrations (2.5, 5 and 10\%) enhanced the growth of both crops. However, negative effects on seed germination, dry matter production and the yield of both crops were found for the effluent concentration of $25 \%$ and above.
\end{abstract}

\section{INTRODUCTION}

The paint industry in Bangladesh since its start around 50 years back is still growing faster than other industries because of the increasing demand of paints locally and internationally. Numerous local and foreign paint industrial units located mainly at Chittagong, Savar, and Gazipur districts of the country are on full swing operation at present. Various waste materials including solid and liquid wastes and volatile organic gases produced in these industries are being continuously released into the environment without or in few cases with partial treatment and affect the basic environmental components such as, soil, water and air ${ }^{(1,2)}$. As Bangladesh is criss-crossed by rivers, the wastewater discharged into the drains or directly into canals from these industries ultimately get mixed with the river water which subsequently contaminate the agricultural land during the rainy season or when used for irrigation purpose. Soil is an efficient purifying medium with a great capacity to receive and decompose wastes and

• Corresponding author 
pollutants of different kinds. It can filter out suspended matter, decompose organic matter by its microflora and precipitate out nutrients ${ }^{(3)}$. However, if the input of the pollutants exceeds the soil purifying limit, the effectiveness of soil microorganism activity is reduced considerably. As result, there occurs an adverse change in the soil physico-chemical properties which consequently affect the growth and development of the crop plants ${ }^{(4)}$.

The industrial wastewater is not merely harmful, it may also be useful for our agricultural purpose. There has been a wide use of this wastewater for irrigation of crops under controlled conditions ${ }^{(5-8)}$. The present study was undertaken to study the impact of paint industry effluent at varying concentrations on the chemical composition of an agricultural soil as well as evaluate its quality as an alternate means of irrigation for crop cultivation.

\section{MATERIALS AND METHODS}

Effluent collection: The effluent used for irrigation of crops in the present investigation was collected from the Berger Paints Bangladesh Ltd., Savar producing both water and solvent based paints. The major contaminants in the effluent streams results from the washing of paint and the resin reactors. The effluent is treated with lime and alum for coagulation of suspended matter and discharged into the environment through a drainpipe after separation of the solid mass. The final effluent after collection in a 20 litre-plastic container was kept undisturbed for about two hours for the settlement of some solid particles at the bottom of the container. The clear effluent from the top was poured into a plastic bucket and diluted as per the requirements to serve the purpose.

Irrigation of agricultural soil with effluent: The soil of $0-30 \mathrm{~cm}$ depth for effluentirrigation was collected from a regularly cultivated agricultural land in Gazaria Upazila, Munshigonj district. The sampling area falls into the agroecological zone- old Himalayan piedmont plain with the dominant loamy and sandy soil texture ${ }^{(9)}$. This soil occurs on the Tista, Karatoya-Bargali, Jamuna, Meghna and Surma-Kusiyara and parts of old Himalayan piedmont plain, and old Brahamaputra and old Meghna esturine floodplains. The soil type is nocalcareous grey floodplain soil. The subsoil is near neutral to slightly alkaline in reaction. Varieties of crops are cultivated in the soil. The pit method was followed for soil collection. Five square pits, each 0-30 cm depth were dug using a steelmade spade on a land of about 1327 Sq. metres. A sufficient quantity of soil was collected from the sides of each pit. The collected sample from all pits were thoroughly mixed on the spot and carried in thick polyethylene bags. In order to study the impact of the effluent, experiments were carried out on this soil contained in earthen-ware pots having no leakage. Seven kilograms of soil was placed in each of the six $25 \mathrm{~cm}$-diameter earthen pots (soil in each pot was $15 \mathrm{~cm}$ deep) and irrigated daily with $500 \mathrm{ml}$ of different concentrations of effluents: 0, 2.5,5 10, 25 and 50\% (V/V). Two other sets of six pots filled with the same amount of soil were used to grow corn and rice using the same amount of effluent concentrations. The irrigation was continued until the crops were matured for sampling. For control groundwater was used for irrigation. 
Collection and preparation of plant and soil samples: When the plants were matured they were cut off at the base and data were recorded for their different parts per plant. Number and mass of seeds produced per plant were recorded. Root system of each plant were carefully taken out of the soil so that fine roots were not removed and washed free of soil by gently soaking it in a bucket of water. All plant samples were dried in an oven at $70^{\circ} \mathrm{C}$ to constant weight. The samples were ground to fine powder in a carbide mortar by a pestle and preserved in a desiccator until analysis.

The effluent-treated soil samples in the earthen pots were allowed to dry naturally. Each sample was then transferred to a plastic bowl and properly homogenized with a clean wooden spatula. An adequate amount of each sample was collected in a polyethylene bag and preserved in a dessicator until further processing. The samples were dried in an oven at $70^{\circ} \mathrm{C}$ overnight as per requirements of the methods where necessary before analysis.

\section{METHODS OF ANALYSIS}

Analysis of physicochemical characteristics and trace elements in soil: The soil samples were ground in an agate mortar with a pestle and passed through a sieve of 100 mesh. Using standard methods the samples were then analyzed for various physicochemical characteristics including $\mathrm{pH}$, cation exchange capacity (CEC) and organic matter ${ }^{(10)}$ and available $\mathrm{Na}, \mathrm{K}, \mathrm{Ca}, \mathrm{Mg}, \mathrm{Fe}$, electrical conductivity (EC) and water-soluble salts ${ }^{(11)}$. The dry combustion method was used for organic determination. The available elements $\mathrm{Na}, \mathrm{K}, \mathrm{Ca}, \mathrm{Mg}$, Fe were first extracted through ammonium acetate $\left(\mathrm{NH}_{4} \mathrm{OAc}\right)$ extraction method. The concentrations of these elements in the extracts were measured by flame AAS method. The available $\mathrm{N}$ and $\mathrm{P}$ were measured by methods developed by Fox \& Piekielek ${ }^{(12)}$ and Nelson et al. ${ }^{(13)}$, respectively. An isotopic source-excited X-ray Fluorescence method was used for trace element analysis in soil samples ${ }^{(1)}$.

Analysis of protein, carbohydrate and trace elements in plant seeds: The dry corn and rice seed samples were ground to fine powder in a carbide mortar with a pestle. The finely ground samples of both crop seeds were then digested and analyzed for total nitrogen content using Kjeldahl method. The protein content in corn and rice seeds was then calculated by multiplying the percentage in seeds by a factor of 6.25 and 5.95 , respectively.

The total carbohydrate content in crop seeds was estimated by difference method. The calculation was done using the formulation: 100- (weight in grams [protein + fat + water $+\mathrm{ash}]$ in $100 \mathrm{~g}$ of sample $)^{(14)}$. Fat was determined by extraction with acetone under refluxing condition ${ }^{(14)}$. Trace elements in seeds of both crops were measured by XRF method $^{(15)}$.

\section{RESULTS AND DISCUSSION}

The paint industry effluent used for irrigation of pot soil was analyzed for its various physicochemical characteristics and the results obtained by Jolly et al are shown in Table 
1 as the average values of eight monthly samples ${ }^{(16)}$. The effluent samples for irrigation purpose and analytical work were collected simultaneously. The effluent was visually found to be almost clear. No odor could be detected in it. It was found to contain much dissolved solid and small amount of suspended soild. The Average BOD and COD values shown by effluent samples were 66 and $101 \mathrm{mg} \mathrm{L}^{-1}$ respectively. The average ratio calculated from $\mathrm{BOD}_{\mathrm{s}}$ and $\mathrm{COD}$ values of effluent samples was 0.66 indicating that the effluents contained mostly biologically degradable substances ${ }^{(17)}$. The effluent was acidic and contained small amount of soluble $\mathrm{N}, \mathrm{P}, \mathrm{Na}, \mathrm{Ca}, \mathrm{Mg}, \mathrm{Cl}^{-1}$ and $\mathrm{HCO}_{3}{ }^{-1}$. For the disposal of industrial effluents into the irrigation land, the standard values for various physicochemical parameters of the effluents have been recommended by the Department of Environment, Bangladesh (DoE). According to DoE the permissible limits for $\mathrm{pH}$, $\mathrm{BOD}_{5}\left(20^{\circ} \mathrm{C}\right)$, COD, dissolved solid, suspended solid and chloride for effluents are 6.09.0, $100 \mathrm{mg} \mathrm{L}^{-1}, 400 \mathrm{mg} \mathrm{L}^{-1}, 2100 \mathrm{mg} \mathrm{L}^{-1}, 200 \mathrm{mg} \mathrm{L}^{-1}$, respectively. It is evident from the effluent characteristic data as described in Table 1 that the values of $\mathrm{pH}$, BOD, total solid and chloride are far below the DoE limits. The trace elements in the effluent samples were also measured and their concentrations were found to be low (Table 1). The only toxic element determined was $\mathrm{Pb}$ whose mean concentration was $20 \mu \mathrm{g} \mathrm{L}^{-1}$ far below its DoE recommended limit $\left(100 \mu \mathrm{g} \mathrm{L}^{-1}\right)$.

Table 1

Physicochemical Characteristic Values and Trace Element Levels of Paint Industry Effluents Collected from Berger Paints Bangladesh Ltd., Savar ${ }^{a}$ (the average value of 8 monthly samples)

\begin{tabular}{|l|l|c|c|}
\hline Physicochemical Parameters & Results Obtained & $\begin{array}{c}\text { Trace } \\
\text { Elements }\end{array}$ & $\begin{array}{c}\text { Concentrations } \\
\left(\mu \mathrm{g} \mathrm{L}^{-1}\right)\end{array}$ \\
\hline Colour & Almost Clear & $\mathrm{B}$ & $<10$ \\
\hline Odor & No detectable odor & $\mathrm{Cd}$ & $<4.5$ \\
\hline $\mathrm{pH}$ & $5.980 \pm 07$ & $\mathrm{Cr}$ & $<4$ \\
\hline EC & $1.22 \pm 0.13 \mathrm{mS} \mathrm{cm}^{-1}$ & $\mathrm{Mn}$ & $25.84 \pm 2.54$ \\
\hline Dissolved + Suspended solids & $1244 \pm 82$ & $\mathrm{Fe}$ & $30.47 \pm 2.21$ \\
\hline Dissolved solid & $1093 \pm 70$ & $\mathrm{Ni}$ & $6.35 \pm 1.67$ \\
\hline BOD & $66 \pm 8$ & $\mathrm{Cu}$ & $6.98 \pm 1.47$ \\
\hline COD & $101 \pm 8$ & $\mathrm{Zn}$ & $59 \pm 7$ \\
\hline Nitrogen & $14.90 \pm 0.22$ & $\mathrm{As}$ & $<10$ \\
\hline Phosphorus & $4.43 \pm 0.66$ & $\mathrm{~Pb}$ & $20.54 \pm 1.73$ \\
\hline Na & $46.38 \pm 2.81$ & & \\
\hline K & $25.71 \pm 3.42$ & & \\
\hline Ca & $558 \pm 78$ & & \\
\hline Mg & $11.66 \pm 1.46$ & & \\
\hline Chloride & $26.55 \pm 1.54$ & & \\
\hline Bicarbonate & $5.63 \pm 0.65$ & & \\
\hline Sulphate & $38.96 \pm 2.41$ & & \\
\hline
\end{tabular}

${ }^{\mathrm{a}}$ The values except for colour, odor, $\mathrm{pH}$ and $\mathrm{EC}$ are expressed in $\mathrm{mg} \mathrm{L}^{-1}$ otherwise mentioned for soluble constituents of the effluents. The contents of this table are the average of the physiochemical and trace element data reported by Jolly et. al. [Ref. 15]. 
The impact of an effluent on the soil depends on its concentration as well as on the levels and nature of its chemical constituents. Though the effluent from the standpoint of its inorganic chemical composition appeared not to be harmful, its direct use for irrigation of pot soil for crop cultivation was avoided as its organic pollutant levels were not known. In order to reduce any effect that might come from the organic pollutants, the effluent was diluted at different concentrations $(0,2.5,5,10,25$ and 50\%) with groundwater and the pot soils were irrigated using these effluents during cultivation. The effect of different dilutions of Berger paints industry effluent on the chemical composition of pot soils without crops are presented in the Table 2. The analysis of original soil has shown values for water soluble salts, $149 \mathrm{mg} \mathrm{kg}^{-1}$; organic matter $1.97 \%$; $\mathrm{pH} 7.0$; electrical conductivity (EC) $233 \mu \mathrm{mhos} \mathrm{cm}^{-1}$; cation exchange capacity (CEC) 9.5 meq/100g; N 5.8.3\%; P $54.31 \mu \mathrm{g} / \mathrm{g}$; Na 0.148 meq/100g; K 0.056 meq/100g; Ca $0.153 \mathrm{meq} / 100 \mathrm{~g} ; \mathrm{Mg} .059 \mathrm{meq} / 100 \mathrm{~g} ; \mathrm{Fe} 3.21 \mu \mathrm{g} / \mathrm{g}$. The soil was moderately rich in organic matter and hence the medium cation exchange capacity ${ }^{(18)}$. It had medium electrical conductivity due to medium concentrations of most of the elements as mentioned above. If the effects of the effluent on the pot soil without crops are considered, changes in the values for water soluble salts, organic matter, $\mathrm{pH}, \mathrm{EC}, \mathrm{CEC}$, $\mathrm{N}, \mathrm{P}, \mathrm{Na}, \mathrm{K}, \mathrm{Ca}, \mathrm{Mg}$ and $\mathrm{Fe}$ of the original soil are observed (Table2). That is, all parameters showed upward trend for $0-10 \%$ effluent irrigated soils and downward trend for $25-50 \%$ effluent-irrigated soils. The increasing mineralization rate of organic matter and hence the more availability of nutrients in the soil irrigated with $0-10 \%$ effluents and the decreasing rate of mineralization of organic matter and hence the less availability of nutrients in the $25-50 \%$ effluent-irrigated soils might be responsible for these observations ${ }^{(19-21)}$. The pot soils with corn and rice crops were irrigated with various concentrations of the effluent and analyzed for parameters required (Tables $3 \& 4$ ). The pot soils without crop plants but irrigated with the same concentrations of effluent were found to show lower values for $\mathrm{pH}$, EC and CEC and contain lower amounts of water soluble salts, N, P, Na, K, Ca, Mg and Fe than the soils of pots with crop plants. This is an indication for the uptake of these nutrients by the crop plants from the effluentirrigated soils. The data given in Tables $3 \& 4$ showed that the rice plants took up more nutrients from the soil than those of corn plants during their growth ${ }^{(4)}$.

The germination of corn and rice seeds was tested using different concentrations of the effluent and the percentage of germination for seeds of both crops are given in Table 4. No variation was found in the percentage of germination of the two crops in the effluent concentration range of 2.5 to $10 \%$. However, higher concentrations of effluent ( 25 to $50 \%$ ) were found to increasingly reduce the germination rate.

Corn and rice plants grown on soil irrigated with the concentrations of $2.5-10 \%$ effluent showed increase in their heights, leaf areas, seed by weights, root dry weights, number of seeds, seed weights compared to the control plants. Plant height showed a maximum increase of $57 \%$ for corn and $14 \%$ for rice grown on soil irrigated with $10 \%$ effluent concentration. The corn leaf increased by $22 \%$ and the rice leaf by $11 \%$. The increased growth response of the crop plants as well as the yield of both crops (number of 
Table 2 and Table 3 
Table 4 and Table 5 
seeds per plant and the dry mass of seeds per plant) grown on soils irrigated with 2.5$10 \%$ effluent concentration can be attributed to the effluent's contributing of the nutrients to the pot soil and hence the availability of nutrients for their increased growth and yields. The uptake of some elements, i.e. N, K, Ca, Fe by the crop plants was checked. The concentrations of these elements withdrawn by the plants was found to be related with the effluent concentrations and hence the free nutrients added by the effluent to the irrigated soils (Table 6). Paint industry effluent may thus serve as a source of nutrients for plant growth. However, as the effluent concentration increased to $25 \%$ and above a reduction in plant height and leaf areas was recorded. The negative trend in plant growth at higher effluent concentrations (25\% and above) is attributed to the interaction of Ca with the other nutrients. At $\mathrm{pH}$ above 7.2, due to the addition of high concentration of calcium from effluent to the soil, the additional "free" Ca is not absorbed onto the soil. Much of the free Ca forms nearly insoluble compounds with other elements making them less available ${ }^{(22)}$.

The seed dry weight of plants grown on effluent-irrigated soil increased to a maximum of $20 \%$ in corn and $22 \%$ in rice at effluent concentration of $10 \%$. The root dry weight also increased to $23 \%$ in corn and $24 \%$ in rice at the effluent concentration of $10 \%$ (Table 7). There appeared a positive relationship between the increments in seed and root dry weights. The crop yields increased on soil concentration of irrigated with low effluent concentration of 2.5 to $10 \%$ but decreased as the effluent concentration was raised to $25 \%$ and above. A positive yield response to low effluent concentration was reported earlier for these crops in several studies ${ }^{(4,7)}$.

The results of total protein and carbohydrate content in seeds of corn and rice grown on soil irrigated with effluent are given in the Table 8. The seed protein contents of corn grown on soil irrigated with the effluent concentrations of $0,2.5,5,10,25$ and $50 \%$ were $7.22,8.18,8.21,8.43,6.34$ and $6.14 \%$, respectively. The respective values for rice were $4.98,5.02,5.36,5.62,4.63$ and $4.49 \%$. The maximum increase in seed protein content with the increase in seed protein content plant ${ }^{-1}$ with respect to the control value were $40.44 \%$ for corn and $47.83 \%$ for rice grown on soil irrigated at the effluent concentration of $10 \%$. However, the seed protein contents of both crops decreased compared to the control values at effluent concentration of $25 \%$ and above. The seed carbohydrate contents of seeds from crops grown at the effluent concentration of 0, 2.5, 5, 10, 25 and $50 \%$ were $80.62,81.59,82.51,83.49,78.02,76.26 \%$ for corn and $81.85,82.92,84.49$, $86.08,80.82,77.24 \%$ for rice respectively. In terms of the increase in seed content of carbohydrate compared to the control value, corn exhibited maximum increase of $24 \%$ and rice of $39 \%$ for the effluent concentration of $10 \%$. But when the irrigation was carried out with the effluent concentration of 25 and 50\%, the contents of carbohydrate reduced to 22 and $27 \%$ for corn and to 13 and 19\% for rice. The increase in the protein and carbohydrate contents of seeds of both crops at the low effluent concentration of 2.5, 5 and $10 \%$ might be due to the facts that the nitrogen taken by the plants at their later stage of growth was transferred to the seeds ${ }^{(8,23)}$. 
(Table 6) 
(Table 7) 
(Table 8) 


\section{CONCLUSION}

It was found from this investigation that the irrigation of agricultural soil with $2.5 \%$, $5 \%$ and $10 \%$ paint industry effluent enhanced the growth of crops increasingly compared to the water irrigation (control). The irrigation with $10 \%$ effluent was the best for this purpose and could fulfil the fertilizer requirements of crops. But a negative effect was observed from the irrigation with $25 \%$ and $50 \%$ effluent. Soil $\mathrm{pH}$ decreased with the increase in effluent concentration. Hence this acidic effluent may be suitable for fields with alkaline soils. This use of the effluent not only solve the disposal problem but also serves as an additional source of liquid fertilizer.

\section{ACKNOWLEDGEMENT}

Authors are grateful to the Ministry of Science, Information and Communication Technology, the People's Republic of Bangladesh for financial grant and the Berger Paints Bangladesh Ltd, Savar for permission to sample effluent for the present study. Authors are thankful to Prof. S. Islam, Department of Soil Science, Dhaka University and Dr. Fazilutun Nesa, Bangladesh Council of Scientific and Industrial Research (BCSIR), for their sincere cooperation in this study.

\section{REFERENCES}

1. M. A. Hossain, "Studies on the Heavy Metal Impact of Paint Industry Effluent on Surrounding Water, Aquatic Plant and Agricultural Soil," M Sc Thesis, Islamic University of Kushtia, Bangladesh, 2004.

2. P. M. Bhabani, "Treatment of Waste Water effluents generated due to the Use of Water Based Paints for removal of Toxic Metals and Organic Pollutants," Ph. D. Thesis, Jadavpur University, Calcutta, India, 1977.

3. G. G. Robeck, J. M. Cohen, W. T. Sayers, and R. T. Woodward, J. Wat. Pollut. Control Fed., 35, 1225, 1963.

4. K. K. Sing And L. C. MisRa, Water Air and Soil Pollut., 33, 309, 1987.

5. E. W. Steel And E. J. Beg, Sewage and Industrial Waste 26, 1325, 1954.

6. A. D. Day, J. L. Streochlein and T. C. Tucker, J. Wat. Pollut Control Fed., 44, 372, 1972.

7. M. Ajmal, M. A. Khan, And A. A. Nomani, Environ. Pollut., (Ser A) 33, 97, 1984

8. R. Sahai, N. Shukla, S. Jabeen and P. K. Sexena, Environ. Pollut., (Ser A) 37, 245, 1985.

9. M. S. Hossain, Soil Classification (With Special Reference to the Soils of Bangladesh), University of Dhaka, Dhaka, Bangladesh, $1^{\text {st }}$ Edn., 1992, Chap. 9 (p. 371) and Chap. 8 (pp. 343-344).

10 Edward J. Rubins, "Standard Methods of Chemical Analysis," Part B, Vol. 2, edited by Frank J. Welcher (Robert E. Krieger Publishing Co. INC., Huntington, New York), $6^{\text {th }}$ Edn, 1975, Chap. 46 (pp. 2312328).

11. J. D. Rhoades and D. Knudsen, G. A. Peterson, P. F. Pratt and R.B. Olson and Roscoe Ellis JR, "Methods of Soil Analysis," Part 2, edited by Page A L (Madison, Wisconsin, U S A), $2^{\text {nd }}$ Edn, 1982, Chap. 10 (p. 170), Chap. 13 (p. 230), Chap. 17 (p. 308).

12. R. H. FoX AND W. P. PieKIELEK, Soil Sci. Spc. Am. J., 42, 751, 1978. 
13. W. L. Nelson, A. Mehlich And E. Winters, Agronomy, 4, 153, 1953.

14. AOAC, Official Method of Analysis (AOAC, International, Arlington, Virginia, USA), $14^{\text {th }}$ Edn, 1984.

15. M. Ali, "X-ray Analytical studies of Trace Elements in Food and Drinks: A Nutritional Assessment in Bangladesh," Ph, D. Thesis, Jahangirnagar University, Bangladesh, 1995.

16. Y. N. Jolly, A. Islam, S. B. Quraishi and A.I. Mustafa, Pak, J. Sci. Ind. Res., 49(2), 82, 2006.

17. J. Tolgyessy, P. Pitter And J. Prousek, "Chemistry and Biology of Water, Air and Soil: Environmental Aspects, Studies in Environmental Science 53," edited by J. Tolgyessy, Elsevier Science Publishers, Amsterdam, the Netherlands, $1^{\text {st }}$ Edn, 1993, pp. 224-232.

18. M. AleXAnder, "Introduction to soil Microbiology," John Wiley and Sons, New York, 1961.

19. A. Ajmal, A. K. Mujahid and A. N. Azhar, Environ. Pollut., Ser A, 33, 97, 1984.

20. O. Igbounamba, Soil Eci., 113, 394, 1972.

21. G. Rajannan And G. Oblisami, Ind, J. Environ, Hlth., 21, 120, 1979.

22. A. Scotт, "Calcium Basics," Spectrum analytic Inc, 1087 Janison Rd, Washington Court House, OH 43160, (800) 321-1562.

23. J. J. JONKER, Stikstof, 42, 206, 1964.

Journal of Bangladesh Academy of Sciences, Vol. 32, No. 1, 41-53, 2008 